\title{
BEST PRACTICES IN NEW PRODUCT DEVELOPMENT: THE ZYRAY WIRELESS CASE STUDY
}

\author{
P. Koekemoer ${ }^{1}$ and A.J. Buys ${ }^{2}$ \\ Department of Engineering and Technology Management \\ University of Pretoria, South Africa \\ philipk@broadcom.com, ${ }^{2}$ andre.buys@up.ac.za
}

\begin{abstract}
Successful high-tech start-up companies are rare. This case study investigates the New Product Development (NPD) process of Zyray Wireless, a very successful startup $3 \mathrm{G}$ technology company that originated in South Africa but relocated to California in the USA. The research looked into the differences between generally accepted NPD best practices and those implemented by this start-up company. Zyray Wireless scored above the industry average in the following categories: customer involvement, project selection, product strategy, technological leadership, and product goal. The best practices for metrics, human resource development, documentation, and change control implemented by Zyray Wireless scored at or below the industry average. The best practice results showed that this very successful start-up company focused more on strategy and engineering and less on process control than average.
\end{abstract}

\section{OPSOMMING}

Suksesvolle nuwe hoë-tegnologie maatskappye is skaars. Hierdie gevallestudie het die Nuwe Produk Ontwikkelingproses (NPO) ondersoek van Zyray Wireless, 'n baie suksesvolle nuwe maatskappy wat in Suid-Afrika ontstaan het maar na Kalifornië in die VSA verskuif is. Die navorsing het na die verskille gekyk tussen algemeen aanvaarde NPO beste praktyke en dié wat deur hierdie maatskappy geïmplementeer is. Zyray Wireless het bo die industriegemiddelde gepresteer in die volgende kategorieë: kliëntbetrokkenheid, projekkeuse, produkstrategie, tegnologiese leierskap, en produkdoelwitte. Die beste praktyke vir maatstawwe, menslike hulpbronontwikkeling, dokumentasie, en veranderingsbeheer wat deur Zyray Wireless geïmplementeer is, het onder die industriegemiddeldes gepresteer. Die beste praktykresultate het getoon dat hierdie baie suksesvolle nuwe maatskappy meer gefokus het op strategie en ingenieurswese en minder op prosesbeheer as die gemiddelde. 


\section{INTRODUCTION}

Most New Product Development (NPD) theory concentrates on companies in their steady-state or market phases. In current NPD theory 'best practices' for NPD are defined. However, these best practices might not all be applicable to the start-up company. How the development process changed and evolved will be investigated.

The different life cycle phases are defined as: Concept, Seed, Product Development, Market Development, and Steady State [1].

Best practices can be divided into the following categories: customer involvement, project selection, product strategy, concept design, technological leadership, documentation, change control, product goal, metrics, process control, and human resource development [2].

\section{THE HISTORY OF THE COMPANY}

A time-line of the history of Zyray Wireless is shown in Figure 1. The history of Zyray Wireless can be divided into various phases. The company was started in South Africa in the middle of 2000. The founders received their initial capital from an investor to build a Wideband Code Division Multiple Access (WCDMA) phone. They used initial capital to secure offices in Midrand, South Africa and began recruiting engineers. By September 2000, 20 engineers were working for the company. The company was divided into two main groups. The first group was involved with the layer 1 software and hardware, while the second group was tasked with developing the layer 2 and 3 software (refer to paragraph 4.7 for detailed information). Michiel Lotter was head of engineering while co-founder Pieter van Rooyen handled the business side of the company.

The first few months were mostly spent learning the necessary specifications and deciding which tools and methods were going to be used. The company essentially used a flat management structure with no real middle management. Some people were tasked with performing some project management duties, but they didn't carry any authority to manage as such. Most meetings involved everyone in the company, and in meetings people used their knowledge from previous experiences to enlighten everyone else. In some cases this was useful, but it also often ended up being very tedious. The biggest asset, however, was that everyone started to get to know everyone else. Some people had worked together previously, but people generally were not aware of the expertise and personalities of most of the other employees.

Towards the end of the year it became obvious to the founders that their current investors were not going to be able to support them. For this reason they started looking at various options. Ted Alexander from San Diego-based Mission Ventures made a due diligence visit to the company in January 2001. He subsequently decided to make a substantial investment in the company.

The initial investors were reimbursed, and this left the company free to continue without their involvement. The new investment, however, carried some prerequisites. 
Firstly, the company had to relocate to San Diego, California. Secondly, the company had to demonstrate working software and hardware at an IEEE show to be held at the end of May 2001 in San Francisco, USA. This would also be the company's debut in the United States.

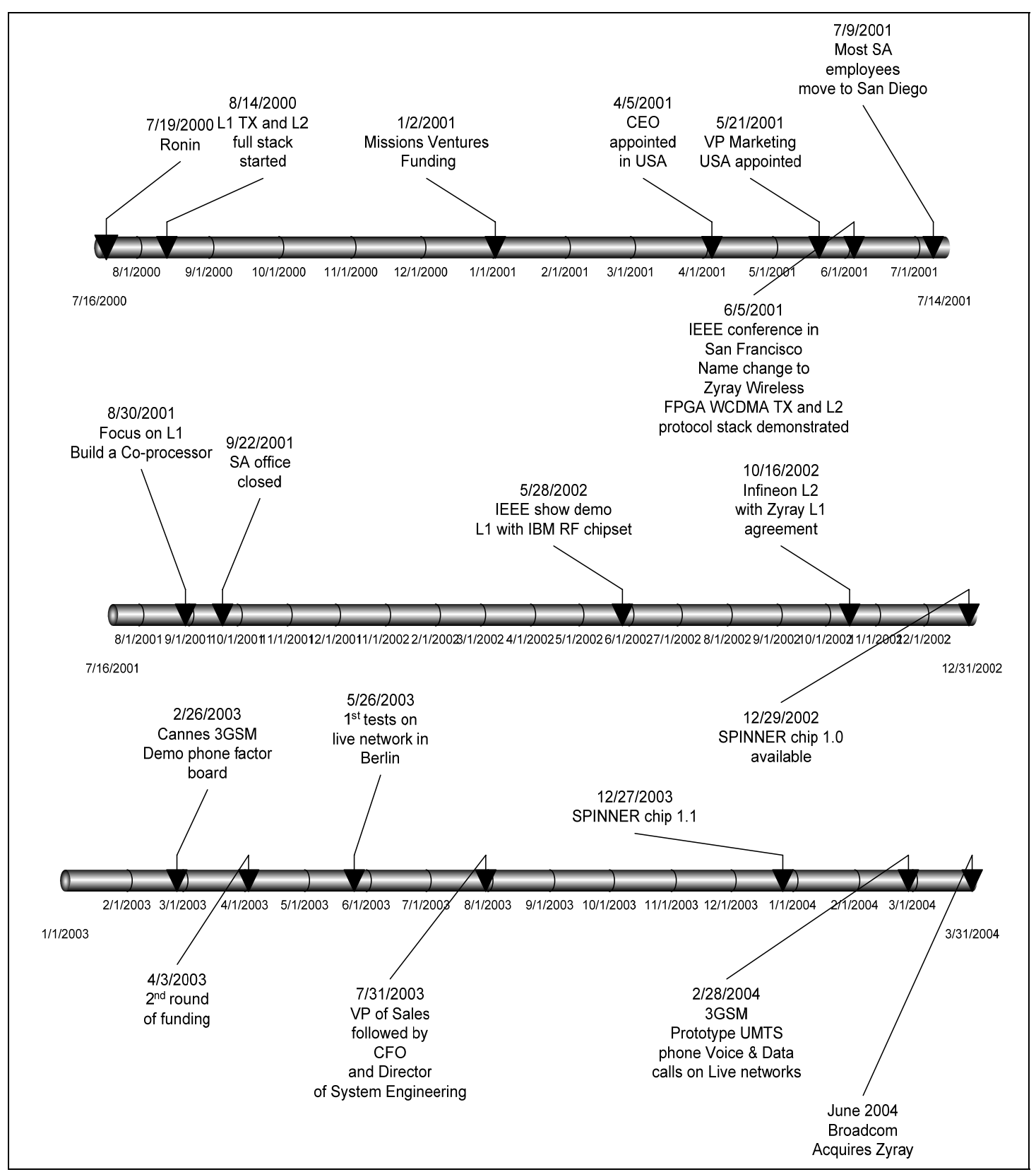

Figure 1: The Zyray Wireless company timeline

The first part of 2001 was therefore spent preparing for the conference and setting up the office in San Diego. The company also made the name-change from Ronin to Zyray, as the Ronin name was already registered in the United States. At this time Werner Sievers, a South African expatriate who has started and led numerous companies over the years, including Dimension Data, and who had moved to America in the early 1990s, was appointed as the company CEO. A vice president of 
marketing was also appointed. Mike Civiello lived in Arizona but agreed to commute to San Diego. Mike spent nearly 20 years working for Motorola in America as well as Japan. While the Zyray team in America was still finding its feet, more people were appointed in South Africa. The understanding was that only people from the original group and not these people would have to move to America. Most people in the original group had no problem whatsoever with moving to America. The additional people were employed primarily to work on higher layer software, including the graphical interface.

By the end of May 2001 two demos were available. The layer 1 demo demonstrated the WCDMA transmitter hardware running in a Field Programmable Gate Array (FPGA) test bed. The layer 2 demo demonstrated mock-up phones running part of the protocol stack, making a data call and running Java applications. The major advantage of the company's participation in the show was getting the Zyray name out, as well as proving to the investors that the company could deliver on its promises.

The next few months were spent thrashing out a new strategy for the company and moving the balance of the people over to the United States. At the end of August 2001 management made some very difficult decisions. Firstly, the office in South Africa had to be closed and everyone who was still working there had to be retrenched. The South African office had become too much of a burden on resources. This change also fitted with the second change in the company. Henceforth the company would concentrate on layer 1 and not implement anything above layer 1 at a commercial level. System engineering and layer 2 people in the company would spend all their time developing solutions to facilitate the successful delivery of a commercial layer 1. Initially it was thought that the IP (intellectual property) could be sold to a chip vendor. Marketing, however, found that no one would trust the start-up if they could not prove that their solution worked inside a chip. Subsequent to receiving this information, more American-based people with chip development skills were employed. This part of the team was headed by Frederic Hayem, originally from France. He had several years of experience working at Philips, and had been involved in the process of designing a full solution that could be handed to a foundry that would then 'spin' or manufacture the chip.

The final strategy decision was made to develop a co-processor chip that would sit next to a current GSM (Groupe Spéciale Mobile) chip and make the GSM chip upgradeable to WCDMA. The chip would therefore be marketed as a WCDMA modem. With this strategy in mind, potential investors and clients were approached.

Part of the strategy was not to develop the Radio Frequency (RF) front-end of the system but to be compatible with any commercially available RF solutions. At the same time IBM in San Diego were developing a WCDMA RF solution. IBM agreed to team up with Zyray for the IEEE microwave convention to be held in Seattle in May 2002. Zyray would demonstrate their FPGA solution working with the IBM RF solution at IBM's booth at the conference. This was seen as the next big deadline for the team as it included a basic working WCDMA receiver. 
The show was successfully completed, and following it Zyray made contact with Infineon, a major German chip manufacturing company. Later that year an agreement was signed with a subsidiary of Infineon called Comneon, who design the higher layer software for cell phones. This was a perfect fit for Zyray's co-processor strategy, as Infineon and Comneon had all the parts of a third generation cell phone except the WCDMA modem part. The co-operation agreement stipulated that Zyray's SPINNER chip, at that point not yet ready for production, had to be available for integration with Infineon hardware and software by the start of 2003. A form factor phone had to be demonstrated at the annual 3GSM conference in Cannes at the end of February 2003. The company had 30 employees at this point.

The first SPINNER chip, version 1.0, became available at the end of 2002. Integration with new hardware and with software started in early 2003, and a phone form factor board was demonstrated at both the Infineon and Zyray booths at the 2003 3GSM congress. The success of the congress stimulated interest in the company both from other venture capital firms and from potential clients. At this point the market started accepting WCDMA as the de-facto standard, as networks in Europe and Asia started operating and experiencing a need for handsets. Zyray secured their second round of funding, headed by Mission Ventures, after the congress. This money would enable them to employ more people, buy more test equipment, and fund the manufacturing of the next version of the SPINNER chip.

The focus of Zyray shifted again at this point. The team had moved from trying to survive and prove that they could functionally adhere to standards and get a chip out, to working on real networks. Because of mounting pressure it was decided to employ a new head of system engineering in the person of Mark Kent. Michiel's work-load had become too much; he would now manage the development while Mark would manage all system engineering efforts. Mark's previous experience helped Zyray to advance their design for the next version of the SPINNER chip, which had to be a fully functional and commercially viable solution.

In May 2003 the company started with field trials in Germany. The main reason for this, apart from the fact that the client was in Germany, was that no networks were available in the United States. This began to put a lot of strain on the engineers who were developing software for the chip, as they had to develop new software and conduct field trials. The solution was to employ a field application engineer (FAE). The FAE would filter any customer queries from the development engineer and only let through questions that he could not answer. Because the development engineers were not involved at the Inter Operability Testing (IOT), the tools used to capture telemetry information from the software on the chip also had to improve. The telemetry tools subsequently became a selling point for the chip, as the high-speed serial link could be used to capture large amounts of data for analysis. Clients looking at the company as a potential partner had to be sure that the company could also deliver proper support for its product. A bug-tracking database was started so that client errors could be logged and analysed by the engineers in San Diego.

One of the contacts made at the 3GSM conference, Broadcom, decided to kick off a development project with Zyray to interface the Broadcom GSM solution with 
Zyray's solution for a laptop PCMCIA card. The layer 2 team, who up to this point were responsible for creating an interface abstraction layer between the layer 1 software and the client stack, took a leading role in the development process with Broadcom.

With markets opening up Zyray had to strengthen and expand its management team. A vice president of sales was appointed, followed by a chief financial officer (CFO). Up to this point the sales position had been the responsibility of the vice president of marketing, while the CFO position had been contracted out as a part-time job.

The second half of 2003 was therefore spent preparing for the release of the next version of the SPINNER chip and doing further field trials with the current SPINNER chip. The company now had 39 employees. At the end of 2003, SPINNER chip 1.1 was successfully manufactured and tested. The chip was then incorporated into an Infineon prototype phone. This completed phone, including GSM, keyboard, display, user interface software and Bluetooth, was then demonstrated at the 2004 3GSM conference in France. The phone garnered immense interest at the conference. The phone was used on live networks in Germany and Italy, and at the conference itself. The subsequent talk was of imminent orders and not just development interest. Zyray now entered the next phase of its evolution. The company had to finish field trials and produce the first version of a commercial product.

In April 2004 Broadcom made a decision to investigate the possibility of acquiring Zyray. Zyray subsequently delayed obtaining investment money and went through a due diligence process with Broadcom. In June 2004 Broadcom announced that it would acquire Zyray for $\$ 96$ million (see appendix 4 for the press release). This was a huge feather in the cap of everyone involved in the company. Broadcom would use Zyray's technology and resources to enter the $3 \mathrm{G}$ market. This strategic acquisition would allow Broadcom to enter the WCDMA market in 2005 and to continue using their current GSM/GPRS solutions. The real start date for WCDMA was 2005, and if a company entered the market too late it might never be able to get in. Broadcom came to the conclusion that Zyray had the right mix of competent people and core technologies to warrant such a big investment.

From the very beginning Zyray had one of three routes to go. The first was to remain private and on their own with strategic partners. The second was to go public; however since the Internet bubble this had proven to be very difficult. The third was to be acquired by a larger company that preferably was already publicly traded. The people in the company saw the acquisition as an acknowledgement of their work ethic, competence, and abilities.

\section{THEORETICAL FRAMEWORK}

\subsection{Customer involvement}

The first three stages of the development process, according to Cooper [3], are: the discovery phase, the scoping phase, and building the business case phase. The customer must be involved in all these phases so that the company can deliver a 
superior product. Gating meetings are held between all the phases in order to screen ideas.

A superior product has to be delivered; one that provides unique benefits and value to the customer [3]. A user-needs-and-wants study can be performed to answer specific questions. These questions are: what does the customer consider to be real value, what is a benefit, and which features, attributes, and performance characteristics translate into benefits and value for the customer?

Proposition 1: Customer involvement will increase over the life cycle of the startup.

\subsection{Project selection}

Cross-functional analysis of new projects is complete and NPD plans are mostly influenced by informal planning activities.

The development funnel is a method, proposed by Wheelwright and Clark [4], to select between different proposals. It eliminates proposals according to the company's product strategy until only the projects that fit the company are left.

During the life of a project, it has to go through various gate decisions. At every gate meeting the project has to be evaluated according to specific criteria. Three types of quality issues exist: the quality of the project execution, the project's fit with the business, and the fact that an action plan for the future has to be evaluated. The aim of the gate meetings is to reduce risk and make 'go/kill' or 'hold' decisions. A twopart decision is made at a gate. First the project is evaluated to see if it is a good project to take on. Next the project is evaluated against the other projects in the company; this forces a resource allocation decision to be made based on project priority. Cooper [3] suggests that the following questions be answered at gate meetings:

- Is the project strategically aligned with the company's business strategy?

- Is there a market need for the project?

- Is the project technically feasible?

- Does the project have a unique advantage for the customer?

- Does it meet all safety, health, environmental and legal requirements?

- Does the project make financial sense?

Proposition 2: $\quad$ The start-up will be forced to make gating decisions regarding which projects to perform.

\subsection{Product strategy}

Technical strategy is defined and should be known throughout the organisation.

Projects must be aligned with internal constraints and capabilities as well as external factors like regulations and competition. The company must choose projects that fit 
the current product mix and therefore leverage the internal capabilities of the company.

The company has to manage its project portfolio. According to Cooper [3] the three main reasons for this are, firstly, the correct new products are fundamental to business success; secondly, new products are a manifestation of the company's business strategy; and thirdly, resources must be allocated to the correct projects.

The three main goals of portfolio management are: value maximization, balance, and strategic direction.

Proposition 3: The start-up company will focus more on product strategy than the rest of the industry.

\subsection{Concept design}

Concepts for new products can be generated by different sources. These sources include employees, customers, new technologies, and suppliers, among others. These new ideas have to be analysed and screened using various criteria before they are selected for further development. If the product is selected for further exploration a concept design is created and a risk analysis performed.

According to Cooper [3] the following should be done when presenting the concept to the customer:

- The customer's interest in the product must be measured.

- Facets of the concept that the customer likes and dislikes must be measured.

- How the customer rates your product against the competition must be measured.

- What the customer expects to pay needs to be ascertained.

- The customer's purchase intent at a specific price needs to be determined.

- Information useful in finalizing the positioning strategy must be gathered.

Proposition 4: Concept designs in the start-up will be done to a limited extent; not more than the industry average.

\subsection{Technological leadership}

According to Bell [1] the company has to have a technology balance sheet. This includes, among other dimensions, a technology base. The technology base includes internal and external sources of components, as well as know-how represented by critical personnel, patents, computers and software, tools, and laboratory equipment and processes. The company has to investigate every aspect of the technology it needs to use to build a product. The company can follow different technology strategies as either the technology leader or follower. In either case, the company has to be able to produce products with superior technologies.

Proposition 5: The start-up company will follow technology leaders. 


\subsection{Documentation \& change control}

The transfer of knowledge between people and the retention of knowledge has been defined in various studies by Numata and Taura [5], Davenport, De Long and Beers [6] and others as a critical success factor. The postulation is that the more a person does a task the better he/she gets at doing the task. Intuitively this postulation makes perfect sense. With the 'capability maturity model' DRM Associates [7] identified the cycles that a product/process has to go through before real understanding of it is achieved. The levels are defined as: initial, repeatable (processes established), defined (cost, schedule, requirements under control), managed (development process is predictable), and optimised. At the optimised level knowledge is shared freely and the whole organisation is focused on improvement.

Formal change control must be implemented across the life-span of the product. The impact of a decision to change a product must be made visible to all the parties involved. Change control is part of the knowledge management process. The impact of the change must be evaluated. This impact could be on cost, schedule slippage, regulatory standards, procurement, manufacturing, and testability, among others.

Proposition 6: In a start-up company change control and documentation will be of secondary importance.

\subsection{Goals and metrics}

First generation phased review processes defined hard decision and design phases for every product [8]. Every phase is gated, and the next phase is not allowed to start unless everything in the previous phase has been completed. This process mainly involves the engineering function. Marketing and support is not part of the design process.

Second generation systems retained a phased approach but the boundaries between the phases got 'softer'. This implied that the next phase could start even if the current phase was not completely finished. Every business could also define its own phases. This process is known as a stage-gate process [3]. The stage-gate process is crossfunctional. Marketing and manufacturing are involved from the outset and play a part in every decision phase.

Third generation management seeks to create a strategically balanced development portfolio in full cooperation with engineering [9]. Development's isolation from the rest of the company is broken; experiences and information are shared across all functions. Because projects are now judged to fit within the strategic framework of the company, resources can be effectively assigned and technological synergy can be achieved throughout the company.

In the stage-gate process of the start-up company, the investment milestones will dictate the goals and metrics. 
Proposition 7: Goals and metrics will closely follow investor or customer milestones.

\subsection{Process control}

Process control or, as Bell [1] puts it, operational management, is the process whereby the organisation manages itself by meeting product specifications, budgetand schedule commitments. The management of the start-up includes use of various techniques, including design reviews, objectives, metrics, staff meetings, and team building, among others.

Proposition 8: The start-up company's organisational structure will change as the product goals change.

\subsection{Human resource development}

The company must be staffed with the correct people. The employees then have to be motivated to perform. Their careers have to be developed and the team must be trained to work together.

Bell [1] quotes John Shoch as saying that "lack of a team is the number one company killer". He goes further and says that although team building is important in any organisation, it is of critical importance in a start-up environment. The employees in a start-up must be able to communicate openly regarding a number of tasks, including defining the product for customers, manufacturing the product, resolving customer problems, meeting operational and financial objectives, and being committed to quality. It is especially important in a start-up that team leaders are technically competent people who are not only involved in management but also actively involved in the design process. This helps to create a better team spirit: the team leader can truly act as a mentor to the people under him or her. The organisation is lean from the start, and it is easier for the team to build respect for management.

Proposition 9: The start-up company's human resource development will be as good as the industry.

\section{RESEARCH DESIGN}

The research method followed was a case study research methodology using positivism as the underlying philosophy.

The unit of analysis for the case study will be the product development process followed in the start-up company. Data was collected over a long period of time, therefore; true longitudinal data could be collected. The data collected spans the time from the start of the company to three years later. This was made possible by the fact that the investigator also works for the company.

This study uses pattern-matching research. Zyray Wireless is studied over a period of 
three years. Specific points in the company's history are identified and data is collected at these points. The points were defined as concept/seed-, product development-, and market phases.

\begin{tabular}{|l|c|c|c|c|}
\hline & $\begin{array}{c}\text { Concept/ } \\
\text { seed }\end{array}$ & $\begin{array}{c}\text { Product } \\
\text { develop- } \\
\text { ment }\end{array}$ & Market & $\begin{array}{c}\text { Dooley } \\
\text { study } \\
\text { values [2] }\end{array}$ \\
\hline $\begin{array}{l}\text { Customer involvement } \\
\text { questions }\end{array}$ & 2.07 & 2.92 & 2.99 & 2.67 \\
\hline Project selection & 2.80 & 3.40 & 3.45 & 3.16 \\
\hline Product strategy & 2.33 & 3.03 & 3.04 & 2.7 \\
\hline questions & 1.50 & 1.71 & 1.92 & 1.96 \\
\hline Concept design & 2.33 & 2.83 & 2.88 & 2.79 \\
\hline Technological leadership & 1.45 & 1.80 & 1.85 & 2.18 \\
\hline Documentation questions & 1.06 & 1.38 & 1.38 & 1.98 \\
\hline Change control & 3.52 & 3.86 & 3.86 & 3.05 \\
\hline Product goal questions & 1.43 & 1.71 & 1.76 & 2.4 \\
\hline Metrics questions & 1.22 & 1.89 & 1.92 & 2.67 \\
\hline Process control & 0.61 & 1.61 & 1.67 & 1.72 \\
\hline Human resource & 1.85 & 2.38 & 2.43 & 2.48 \\
\hline development & 0.850 & 0.849 & 0.835 & 0.469 \\
\hline Average & 0.922 & 0.921 & 0.914 & 0.685 \\
\hline Stand dev & 1.29 & 1.69 & 1.73 & 2.31 \\
\hline Variance & 2.61 & 3.21 & 3.24 & 2.87 \\
\hline Execution of NPD & & & & \\
\hline Strategic implementation & & & & \\
\hline
\end{tabular}

Table 1: Zyray Best Practice categories results

In this case study data collection is done by means of company documents, interviews, and participant observations. The interview questionnaire is an adapted version of that used in the study by Dooley [2]. The results from the study by Dooley are used as the pattern that results will be matched against. If the results obtained are the same as the Dooley results, this would indicate that a start-up is no different from any other organisation. If the results do not match the pattern shown by the Dooley survey, however, we can conclude that Zyray is different from other companies. Because patterns are matched over the life-cycle of the company, the results might also indicate when the start-up is similar to - and when it is different from - other companies.

\section{RESEARCH RESULTS}

\subsection{Best practice scores}

The average values for the best practice items per life-cycle phase are tabulated below. The information was obtained through interviews with key employees (as 
noted above). Note that the concept and seed phases are shown as one phase. The steady state phase is not in the analysis, as the company never entered this phase. The original scores from the study by Dooley [2] are listed in the last column. The medians of all the scores as well as the variance and standard deviations are also shown.

The normalised graphs in Figure 2 were drawn using the information in Table 1.

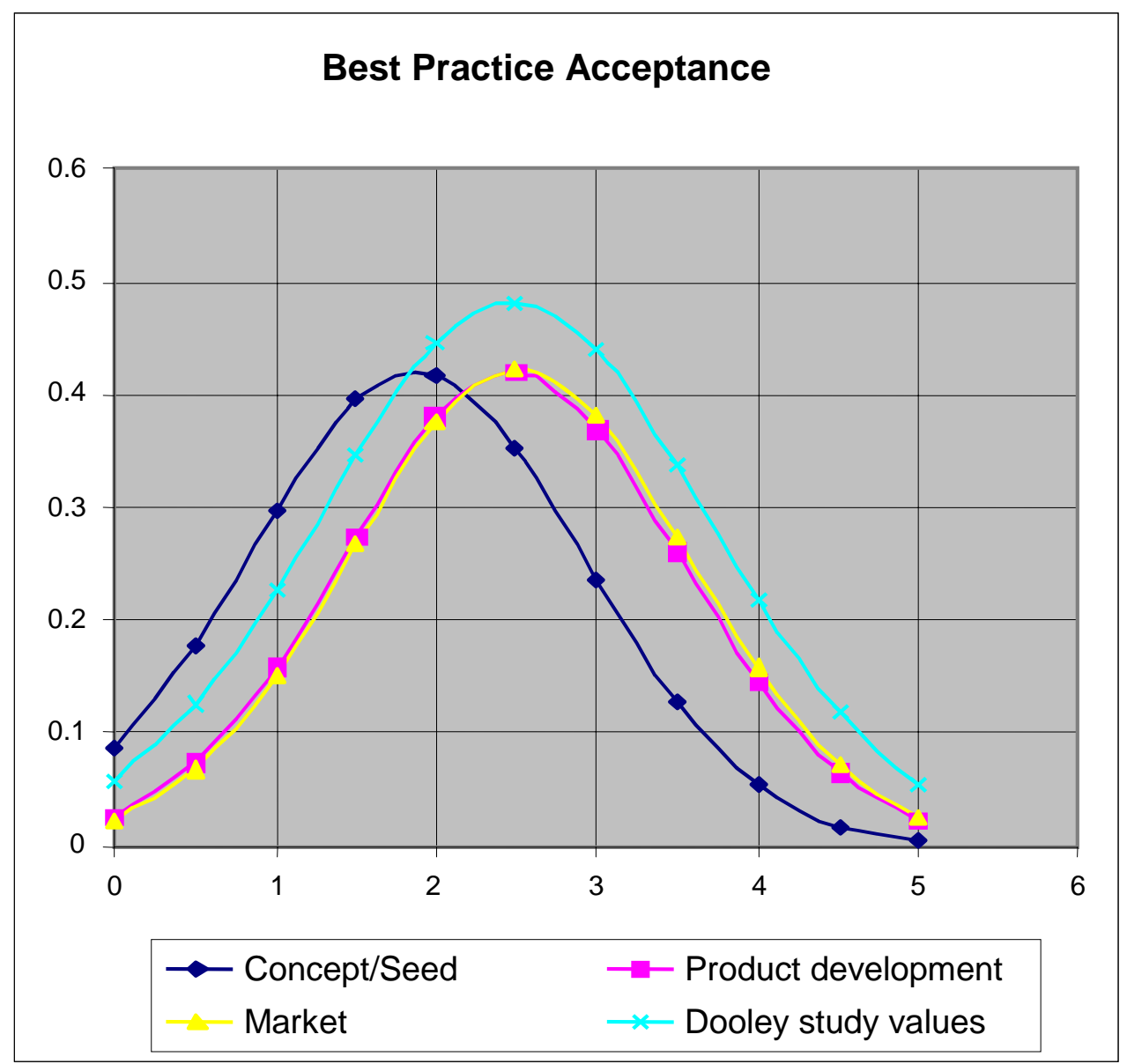

Figure 2: Normalised acceptance of best practice categories

Dooley [2] found that NPD success was influenced more significantly by best practices controlling the strategic implementation of NPD (project selection, goals, technological leadership, product strategy, and customer involvement) than by NPD best practices associated with the execution of NPD (process control, metrics, documentation, and change control). They also found that best practices associated with strategic implementation were more widely adopted than best practices associated with controlling and executing product development.

\subsection{Customer involvement}

Zyray did not initially have a marketing department or a person with marketing experience that could build a marketing team. Only when the company moved to the 
United States and employed a seasoned CEO did the company employ someone with marketing experience.

Proposition 1: Customer involvement will increase over the life cycle of the start-up.

This proposition was found to be true. Initially customer needs were identified by the founders and later by the marketing team. The averages in the customer involvement best practice category were found to have increased during life cycle phases from an initial 2.07, to 2.92 in the development phase, and finally 2.99 in the market phase. It can be see from the results produced through the research questions that customer involvement scores increased over time.

One reason why customer needs were better identified over time was that, as more people became available, it became possible to visit more potential customers and industry leaders. While the founders could spare only part of their time resolving customer needs, the marketing department could actively chase down customer needs as part of their responsibilities.

Not employing someone with marketing skills could have been a critical oversight on the part of the founders. It is also possible that in the seed/concept stage, the start-up was catering to a different customer. The customers in the initial stages of the startup were the venture capitalists. The start-up had to get money from investors, and therefore the product was defined by the needs of the investors rather than by actual customers.

The problem with this approach - catering only to the needs of the venture capitalists - was that the start-up was not focused on a reasonable goal. Initially, Zyray was going to build an entire phone. The problem was that this was what investors wanted to hear, and as a result that was what they were 'sold'. In later stages, however, the focus shifted to the real customers who would buy a product rather than the promise of a product. Fortunately for Zyray, they managed to sell to the investors as well as real customers.

\subsection{Project selection}

Proposition 2: The start-up will be forced to make gating decisions regarding which projects to perform.

This proposition was found to be true. Zyray started with a much broader scope to its product. Over time, and particularly after employing a CEO and vice president of marketing, the scope of the project became more focused. The major driving force in this change of scope was found to be economic criteria. Resources drove economic criteria available in the current budget.

Zyray has, for most of its existence, only had one product. What the product actually looks like and the boundaries of the product have, however, changed over time. Initially the company was going to make the physical layer hardware and all the software layers above it as well. The company was going to produce a WCDMA 
phone. However, when the company employed a CEO and started the marketing department, it was quickly found that producing all of these elements would be too much work for such a small group of people. Timmons [10] mentions the importance of focus for start-up companies. The company roadmap was therefore redefined to include only the physical layer hardware in the shape of a microchip, the physical layer software, and a layer of integration software. This helped the company to focus its resources, which in turn helped it to achieve all the milestones set. This gave the company an advantage when negotiating with venture capitalists in subsequent funding rounds.

The start-up company did not have a formal stage gate process in place. However, various events in the company's life cycle forced the project gating events to be on an ad hoc basis. Some running projects were stopped after 'gating' events. One such event was at the expansion of the management team. This coincided with the time when the company already had investment capital and had to analyse whether the initial project goals were achievable.

No significant changes were made to the product roadmap following this gating event. No formal processes were ever implemented to have specific gating meetings for various projects. The management team and the board, however, continuously looked at what the company was doing and how various projects fitted in with attaining the milestones.

It was therefore found that because the company only had one product, the project selection process was never formalised. The informal project selection process, however, had economic criteria as its biggest driving factor.

\subsection{Product strategy}

Proposition 3: The start-up company will focus more on product strategy than the rest of the industry.

The scores for the product strategy best practice category improved over the life cycle of the company. The score increased from an initial 2.33 to 3.03 and finally to 3.04 . The industry average was 2.7 , indicating that the company's strategy was above average for most its life cycle.

From the answers given to the questions about product strategy, it is clear that this category was one of the most important for the company. Management closely followed the progress of projects and ensured that all funding constraints were adhered to. People agreed that project funding was based exclusively on potential contribution to business. All projects within the company were done to further the progress of the one product being developed. The product portfolio consisted of a single product.

Market research was performed and used as input for the product requirements. The product requirements were again aligned with the company strategy. The original company strategy was to build the specific product. At this point the company 
strategy was to enable WCDMA in next generation cell phones. The product to be developed was a WCDMA chip; the product and project strategies were one and the same.

The start-up company closely followed the three different metrics given by Cooper [3]. Zyray showed that choosing the correct product and company strategy, and then aligning all resources with the product development of this product, are necessary to achieve success.

\subsection{Concept design}

Proposition 4: Concept designs in the start-up will be done to a limited extent; not more than the industry average.

In the industry, a score of 1.96 was found for the concept design category. The startup always scored lower than the industry average $(1.5,1.71$ and 1.92). This evidence therefore supports the proposition that the start-up will not spend more time than the average company in the industry on concept designs.

Marketing solicited information from various sources. These sources included network operators, phone manufacturers, and suppliers. The information gained from these sources was used to create the company strategy and product roadmap. The proposition that marketing dominated the concept design was found to be true.

This marketing-dominated concept design created a successful strategy. The company strategy was taken to investors and potential clients that needed the technology Zyray provided. When Zyray brought out its first chip they also signed a co-operation agreement with their first client. The product perfectly fitted the needs of the clients that the company was targeting. The company could only have formulated a successful strategy by gathering the correct information. Having marketing take the concept product strategy to the correct clients proved to be essential to the success of the company. As a result of Zyray delivering the correct product to the market, Broadcom finally acquired Zyray.

The concept strategy was formulated in the second half of 2001 and implemented as company strategy soon after this. The company could focus its resources from this point forward on delivering a product. The SPINNER chip 1.0 was delivered at the end of 2002. SPINNER 1.1 chip followed at the end of 2003, and the company was acquired in 2004.

Zyray's success was therefore plotted in 2001 by the successful prediction of what the market would want 3 years later. The concept design formulated early on would define the strategy of the company for years to come.

\subsection{Technological leadership}

Proposition 5: The start-up company will follow technology leaders. 
Looking at the technology leadership category averages it can be seen that it did not change much over the life cycle of the company. In the market phase the technology leadership category of Zyray scored a high of 2.88. The industry average was 2.79, which put Zyray right on the industry average (within one standard deviation). This score shows, therefore, that the company did not stand out in developing new technologies.

A technology balance sheet was said to be an important part of the company's strategy. The company had to develop superior products using technology, adhering to industry standards and hiring competent people so that competitive advantage could be built and sustained.

The start-up company had to be evaluated against other start-up companies. Towards the last year and a half of the company's existence, it started to employ people with relevant knowledge from other failed start-up companies in the same field.

Zyray managed to run a tight schedule on the engineering front and never missed a milestone. Both chips produced by the company also worked. If any of the chips had failed, the company would have been in serious trouble and very close to permanently closing its doors. Making a chip is very expensive, and a balance has to be kept between making a chip and developing more mature technology to put in the chip. The risk increases if the differences between chips are bigger. SPINNER 1.1 ended up being network tested inside a commercial phone.

Zyray therefore developed one test chip, and the second chip had to be good enough to put in a commercial product. Zyray set the bar for all other start-ups in the same field. When taking the complexity of WCDMA into account, this is a phenomenal achievement. When the company started no 3G networks existed; in 2003 and 2004 test $3 \mathrm{G}$ networks started up in Europe with some commercial networks following. Just comparing the $384 \mathrm{kbps}$ download speeds over a wireless connection with a dialup modem at $56 \mathrm{kbps}$ should already give an indication of the level of complexity of the technology.

\subsection{Documentation}

Proposition 6: In a start-up company, change control and documentation will be of secondary importance.

It was found that only the necessary documentation was kept. The averages for documentation questions were well below the industry average. The documentation scores started at 1.45 , increased to 1.80 and finished at 1.85 . The industry average was 2.18 . The proposition was found to be true.

The reason for neglecting documentation could be attributed to resources. Technical milestones drove the budget of the start-up. Anything that did not show an immediate advantage in the start-up was of secondary importance. The start-up did not have a department or a person exclusively assigned to handling documentation issues. 
Various databases were used by the start-up to make documentation easier. The first product used was DOORS. The company's engineers, however, never accepted this tool as it forced the user to use a new system instead of Microsoft Office products. The tool that followed DOORS, called Sharepoint, was from Microsoft. The Sharepoint program proved to be successful, as it enabled the users to use the programs they knew in order to generate and manage documentation.

The types of documentation that the company could not live without were: WCDMA system design specifications, ASIC design specifications (used as input by the chip manufacturer), and documentation detailing the interface of the product to clients.

\subsection{Change control}

Proposition 6 stated that documentation and change control would be of secondary importance. The average for change control was found to be well below the industry average of 1.98. It started at 1.06 and then moved to and stayed at 1.38. As stated earlier, this proposition was found to be true.

The biggest influence on change control in the company was the use of a change request or bug tracking system. The company chose to use a product called Test Track Pro.

Change requests can be entered into the database and a responsible person can then be assigned to resolve the change request. When it came to actual intellectual property, everything was divided into two categories. The first category was all source code - be it firmware, hardware, or mathematical models. This was kept in a freeware repository called CVS. Everything else was kept in the previously mentioned Sharepoint database.

The balance of the documentation was technical documentation. Although marketing and management kept information, the change control system only applied to engineering.

Change control and documentation became more necessary as the company acquired more clients. Many documentation efforts were driven by the requirements of the client. The bug tracking system became necessary the moment the engineering department started developing the product and supporting the product at the client level. Previously one person could keep track of all the changes and all the responsible people; this became impossible, however, when the company had to start supporting clients.

There is no doubt that a successful company has to have a system in place to track changes and to keep information. The most important step of such a system in the specific start-up was to get all the engineers to agree to use the chosen tools. The engineers in the company did not agree to use DOORS because it was cumbersome; but the moment the company started using tools that truly helped the process and did not get in the way of people doing the real engineering work, the tool was accepted and used. 
Change control was exclusively implemented for the engineering function, starting in the product-developing phase. No change control was kept for concepts or marketing.

\subsection{Product goals and metrics}

Proposition 7: Goals and metrics will closely follow investor or customer milestones.

External and internal development goals were aligned with investor milestones. If the company achieved a milestone, the investors would continue investing. The proposition was found to be true.

From the averages found it is evident that metrics and goals were approached quite differently in the start-up than in the industry. Metrics scored very low in the startup, starting at 1.43, going to 1.71 , and ending at 1.76 . The industry standard for metrics is set at 2.4. Product goals, however, scored highly, starting at 3.52 and ending at 3.86. The industry average is 3.05 .

The stage gate process outlined gate meetings for the various projects in the company. At these gate meetings the project metrics were evaluated and 'go/no-go' decisions were made. The metrics could be financial, strategy, or engineering metrics. The stage gate process was implemented internally. Zyray did not implement a formal stage-gate process. The various functions communicated in such a way that co-operation existed between them, and information and requirements were fed back into the design process. Gate meetings as such did not exist in the company.

The company had a single product and the development of that product had to continue. Financial metrics were taken by management as a tight budget had to be kept. In engineering no formal metrics were kept, apart from making sure that the product worked.

Externally, however, investors in collaboration with management and the board defined very hard goals to be achieved. These goals put 'go/no-go' decisions on next round financing decisions. If the goals were not met the financing would be stopped. The metrics used at these milestones were technical. The chips the company produced had to work, or alternatively a demonstration at a trade show had to be successful.

Zyray delivered at every milestone set for them and in some cases over-delivered. A case in point was that the company received the first chip on 31 December 2002; one and a half months later, at the biggest GSM tradeshow in the world, the working chip was demonstrated inside a form factor cellular phone. The goal set for this milestone was to have the chip on a big development platform. The requirement was literally an order of magnitude easier to achieve than what was delivered. 
Over-achieving on goals set was crucial to gaining the trust of investors and clients, and finally to the company being bought for nearly a hundred million dollars.

\subsection{Process control}

Proposition 8: The start-up company's organisational structure will change as the product goals change.

The company structure changed when the product strategy changed. It also changed when the company signed up clients and the product became more mature. Therefore the proposition was found to be true.

Process control in the company did not score very highly in the data collected. It started with an average of 1.22, improved to 1.82, and ended at 1.92. All these scores are still well below the industry average of 2.67 . The discrepancy is partly because the process control questions cater more to well-established companies. The documentation of processes, the formal selection of suppliers, and communication with manufacturers did not exist in the start-up company.

The start-up has to define the way everything is done. The engineering manager has get people with different skills and experiences to agree on how to do things in the new company. Engineers from different backgrounds are used to doing things differently, and some time has to pass during which agreement is reached on how the company processes will work. Because of limited resources all processes are designed as they become necessary; therefore, more processes are formalised over time. Input from various sources has to be taken into consideration, but in the end the engineering manager has to make the final decision, and everyone has to respect and follow the processes established.

At its largest, Zyray employed forty people. This was still relatively small for a technology company, and communication was still relatively easy. The company also had only one product. It therefore did not have to formalise many processes. In many cases a single person was responsible for talking with suppliers and manufacturers. In such a case only the person's own processes have to be followed. The company does not need a formal process to govern when one person is in control.

The biggest advantage the start-up has over well-established companies is that it can move more quickly than anyone else. Companies with 'tiger teams' still have to work within the overall company bureaucracy. The start-up can quickly adapt itself to new situations and requirements. People are also open to thinking and acting more freely, and therefore are able design quick solutions to problems rather than waiting to be formally tasked to do so. This is also the case for the use of tools. Barring financial constraints, new tools can be quickly bought and used. There is no need to standardise over the whole company, as the engineers are typically co-located. 


\subsection{Human resource development}

Proposition 9: The start-up company's human resource development will be as good as the industry.

While the human resource best practice category started with a low of 0.61 , it increased to 1.67 in the market phase. This score is on a par with the industry average of 1.72. Personnel felt that career development and recognition were easily attained. Everyone had to be willing and able to perform at his/her peak and feel that they made a measurable difference. All employees were given ownership in the company. Skills were built because employees had to work outside of set fields and take ownership of the company goals. Because of the size of the company everyone was privy to management, marketing, sales, and engineering information. Each person gained more experience than they would have, had they worked for a big corporation.

The start-up company has to have the correct product strategy and excellent employees. Everyone has to show leadership and be willing to work independently. The data showed that the rules and regulations in the company were very limited. The individual had to take ownership, had to work well within the team, and could not expect to be led or 'spoon fed' at any point. New solutions had to be sought both technically and in management. There was no time to watch over anyone's shoulder and make sure they got the job done. Each person had to have the strength to learn and finish any task.

The success of the start-up company is tightly coupled with the skills of the individual people in the company, and how well these individuals form a strong team.

\section{CONCLUSIONS}

Current theory and best practice categories focus mainly on well-established companies. Although literature is available on the specific needs of the new or startup company, most product development techniques focus on established companies.

The study showed the following 10 important points:

1. In the initial phases the start-up's customers were the venture funds.

2. The project selection process was informal but driven by economic criteria.

3. The company had to choose a product strategy early on and then had to develop the product according to this strategy.

4. The marketing team developed the concept design, and they influenced the future of the company because they dictated the product strategy.

5. The company followed a technology follower strategy. The technological competency of the team was of such a high standard that they developed a product after very few iterations.

6. Internal documentation was limited, but external documentation with clients and manufacturers had to be of a high standard. 
7. Change control was limited to the engineering function.

8. Over-achieving on goals set by itself and investors was of critical importance.

9. Process control was kept to a minimum, and the company could react very quickly to changing situations.

10. Establishing a strong team is of critical importance to the success of the company.

The purpose of this study was to show the difference between the best practice categories taken over a large industry sample and those of the start-up company. The differences were shown by comparing an industry wide survey with the same survey taken within the company. Doing this comparison also improved the validity of the study: showing how the company compared with the industry qualifies the propositions made earlier in this dissertation.

Firstly, Dooley [2] found that NPD success was influenced more significantly by best practices controlling the strategic implementation of NPD (project selection, goals, technological leadership, product strategy customer involvement) than by NPD best practices associated with the execution of NPD (process control, metrics, documentation, change control).

The start-up company followed the theory that strategic implementation categories influence the development process more than the execution categories. The strategic categories started at an average of 2.61, increased to 3.21 and ended at 3.24. The industry average is set at 2.87 . The strategic categories are well above the industry average. These averages show that the focus of the start-up was on product strategy and on the engineering of the product even more than the industry average.

The best practices associated with the execution of product development were, however, much lower than the industry average. They started at 1.29 , increased to 1.69 , and ended at 1.73 . The industry average was substantially higher at 2.31 . This shows that the start-up rejected the process control categories more than the industry average.

\section{REFERENCES}

[1] Bell, G.C., 1991. High Tech Ventures: The Guide for Entrepreneurial Success. First Edition. Addison Wesley: Reading, Massachusetts.

[2] Dooley, K., Subra, A., Anderson, J., 2002. Best Practices in New Product Development: Adoption Rates, Adoption Patterns and Impact. University of Arizona, http://www.public.asu.edu/ kdooley/papers/npdbp.pdf visited on 20 June 2004.

[3] Cooper, R.G., 2001. Winning at new products; Accelerating the process from idea to launch. Third Edition. Perseus Publising: New York.

[4] Wheelwright, S.C. and Clark, K.B., 1992. Revolutionizing Product Development. First Edition. The Free Press: New York.

[5] Numata, J. and Taura, T., 1996. A Case Study: A network system for knowledge amplification in the product development process. IEEE 
Transactions on Engineering Management ,Vol. 43, No 4:356-366, November 1996.

[6] Davenport, T., De Long, D. and Beers M., 1998. Successful Knowledge Management Projects. Sloan Management Review, Winter 1998:43-57.

[7] DRM Associates (private communication).

[8] Cooper, R.G., 1994. Third Generation New Product Process. Journal of product innovation and management, $1994 \mathrm{nr}$ 11:3-14.

[9] Roussel, P.A., Saad, K. and Erickson, T., 1991. Third Generation R\&D. First Edition. Arthur D. Little: Boston.

[10] Timmons, J., 1999. New Venture Creation: Entrepreneurship for the 21st Century. Fifth Edition. McGraw Hill. P. 521. 